\title{
Artéfacture : des machines qui pensent aux machines qui donnent à penser
}

Bruno Bachimont

\section{(2) OpenEdition}

1 Journals

Édition électronique

URL : https://journals.openedition.org/tc/571

DOI : $10.4000 /$ tc. 571

ISSN : 1952-420X

Éditeur

Éditions de l'EHESS

\section{Édition imprimée}

Date de publication : 1 novembre 1995

ISSN : 0248-6016

\section{Référence électronique}

Bruno Bachimont, "Artéfacture: des machines qui pensent aux machines qui donnent à penser ", Techniques \& Culture [En ligne], 23-24 | 1995, mis en ligne le 09 décembre 2005, consulté le 29

septembre 2022. URL : http://journals.openedition.org/tc/571 ; DOI : https://doi.org/10.4000/tc.571

Ce document a été généré automatiquement le 29 septembre 2022.

Tous droits réservés 


\section{Artéfacture : des machines qui pensent aux machines qui donnent à penser}

Bruno Bachimont 